\title{
Iranian English as a Foreign Language (EFL) Learners' Argumentative Writing Performance in Private Language Institutes
}

\author{
Vahid Nimehchisalem ${ }^{1}$, Masoud Machinchi Abbasi ${ }^{2}$, Amirtohid Ebrahimzadeh ${ }^{2} \&$ Seyed Ali Rezvani Kalajahi ${ }^{1}$ \\ ${ }^{1}$ Faculty of Modern Languages and Communication, Universiti Putra Malaysia, Malaysia \\ ${ }^{2}$ University of Tabriz, Tabriz, Iran \\ Correspondence: Vahid Nimehchisalem, Faculty of Modern Languages and Communication, Universiti Putra \\ Malaysia, Malaysia. E-mail: vahid@upm.edu.my; nimechie@gmail.com
}

Received: December 24, 2014 Accepted: February 23, 2015 Online Published: May 15, 2015

doi:10.5539/ass.v11n15p96 URL: http://dx.doi.org/10.5539/ass.v11n15p96

\begin{abstract}
Literature on Iranian English as a Foreign Language (EFL) learners' problems in their writing skills is lacking. The present study analyzes a group of Iranian EFL students' written samples to diagnose their main area(s) of difficulty in writing argumentative essays. For this purpose, a sample of 69 argumentative essays was collected. Two raters used an analytic argumentative writing scale to score the samples. Based on the scores assigned to their written samples, majority of these students indicated excellent 'content' and 'organization' levels; competent 'task fulfillment', 'vocabulary', and 'style' levels; modest 'grammar' levels; and finally, very limited levels of 'mechanics' skills. The findings indicate the positive and promising role of English language institutes in students' writing skills. The results have pedagogical implications that will help English language instructors and program developers in Iranian English language learning-teaching institutes improve the outcome of their instruction. Further research is necessary to study the EFL writing skills of Iranian school students.
\end{abstract}

Keywords: Argumentative writing, Iranian English language learners, English language institutes

\section{Introduction}

Argumentative writing ability is one of the essential skills that most English language learners are expected to have. Toulmin, Reike, and Janik (1984) defined argument as a set of interrelated claims and supporting statements that enforce the arguer's position. Argumentative writing involves the process of stating a claim, providing data to support that claim, acknowledging the possible counter-arguments and offering rebuttals (Toulmin, 1958). Most language learners have partial understandings of argument, for instance a for-and-against structure sandwiched between introduction and conclusion. Learners need to develop analytic and evaluative skills in order to write effective argumentative essays (Wu, 2006). Additionally, learners need to be aware of the appropriate schematic structure, style, and register, for effective presentation of their position (Swales, 1990). However, literature related to the Iranian English as a Foreign Language (EFL) learners' argumentative writing skills is lacking.

In Iran English is commonly learned as a foreign language (EFL) in two very diverse ways. Publicly, it is offered as a school subject starting from the Guidance School (equivalent to secondary school elsewhere) about 2 hours per week. The syllabus is designed in a traditional manner with a primary focus on grammatical rules, vocabulary knowledge, reading comprehension, and translation skills in a highly exam-oriented context. The school English language textbooks are developed by the Ministry of Education and prescribed to be taught and tested throughout the country. Limited attention is paid to students' listening, speaking and particularly writing skills in their actual sense. Admittedly, there are guided writing activities in the textbooks, but the activities are meant to reinforce students' knowledge of new grammar rules or vocabulary items they have just been taught. Students' paragraph development, essay writing, or argumentation skills are ignored in the syllabus. Indeed, research findings indicate Iranian "school students do not receive any formal L1 and L2 argumentative or academic writing instruction" (Khodabandeh, Jafarigohar, Soleimani, \& Hemmati, 2014, p. 255). In their evaluation of Iranian high school English Language Teaching (ELT) textbooks, Azizifar et al. (2010) found that these materials are limited to mechanical drills and fail to encourage learners to negotiate and develop communicative skills. In a similar study, Safarnavadeh, Aliasgari, Mosapour, and Ananisarab (2009) found that 
the main course objective of Iranian school English language subjects was grammatical precision and mechanistic application of models.

Alternatively, some students simultaneously enroll in private language institutes after school hours. These institutes often follow learner-centered methods. In contrast to the English subject offered at schools, these institutes focus on all language skills (listening, speaking, reading, and writing) as well as sub-skills (vocabulary, pronunciation, grammar, and spelling). Most of these institutes are also exam-oriented; however, they aim at preparing learners for international English tests, such as Tests of English as a Foreign Language (TOEFL) or International English Language Testing System (IELTS). The ELT learning-teaching materials used in these institutes are almost always selected from commercial coursebooks, like Interchange (Richards, 2012) or Cutting Edge (Cunningham \& Moor, 2005). The students who complete the elementary, intermediate, and advanced levels offered at private language institutes often acquire communicative skills in the English language. Since most private language institutes are established for instructional and/or commercial purposes, limited literature is available on their learners' English language skills, which necessitates investigation in this area.

\subsection{Objective and Research Questions}

The objective of this paper is to explore the performance level of a group of Iranian EFL learners in their argumentative essays. The following research questions were addressed to meet this objective:

1. To what extent can the students fulfil the task requirements in their argumentative essays?

2. To what extent is the content of their argumentative essays effective?

3. To what extent do the students' argumentative essays exhibit their writing organization skills?

4. To what extent do the students use the vocabulary accurately and appropriately in their argumentative essays?

5. How effectively the students handle the style in their argumentative essays?

6. How accurately is grammar used in the argumentative essays?

7. To what extent do the students use mechanics accurately in their argumentative essays?

\subsection{Previous Studies on EFL Students' Writing Problems}

Research findings have shown that argumentative writing poses rhetorical difficulties for ESL student writers. AI-Abed-AI-Haq and Ahmed (1994) investigated the problems in argumentative essays written by university level ESL students $(n=62)$ in Saudi Arabia. They found that these students lacked three major abilities, including:

1. completing and balancing the arguments and counterarguments;

2. developing, supporting, and organizing persuasive arguments; and

3. clarifying and qualifying the arguments.

Zhu (2009) examined Mexican graduate students' argumentative writing difficulties in English and found that the students perceived the most difficult aspect of English argumentative writing to be its rhetorical aspects. Research shows native and non-native writers differ in the way they handle counterarguments (Hinkel, 1999). Comparison of English-speaking and Spanish-speaking students' writing has indicated that the latter prefer a more elaborate style in their argumentative writing (Lux, 1991).

Several studies are available on Iranian EFL leaeners' writing difficulty. In their analysis of the quality of Iranian EFL learners' argumentative essays, Dastjerdi and Samian (2011) reported frequent cohesion anomalies which they attributed to the learners' poor linguistic (especially syntactic and semantic) awareness as well as inaccurate knowledge of the English cohesion rules. Khiabani and Pourghassemian (2009) studied 120 Iranian EFL students' essays written in L1, and with an interval of one month, written on the same topic in L2 under four conditions differing in audience and/or language of thinking. They aimed at investigating the differences in organizational patterns and the quality of L1/L2 argumentative writings of Iranian EFL students in the presence of native-nonnative hypothetical audience by using L1/L2 think-aloud procedure. Two raters evaluated the essays in references to the location of main idea, quality of writing, and macro-level rhetorical patterns. Their findings indicated insignificant differences between the organizational patterns of L1and L2 writings but better quality of L1 writings. Hemmati (2001) conducted a qualitative study to identify Iranian university level students' $(\mathrm{n}=30)$ vocabulary related problems while writing in English. She presented an in-depth account of varying types of vocabulary problems that her participants experienced in the process of writing. She attributed these problems to the learners' linguistic competence and/or performance. Birjandi, Alavi, and Salmani-Nodoushan (2004) report that most Iranian students face macro-skills (grammar and vocabulary) as well as micro-skills (content and organization) problems while writing in English. They argue that Iranian EFL student writers focus 
on ideational meaning, ignoring the interpersonal meaning (which indicates the relationship between the writer and reader) as well as the textual meaning (which aids readers in navigating through the text). Shokrpour and Fallahzadeh (2007) investigated the Iranian medical students and interns' EFL writing problems in Shiraz University of Medical Sciences. They found that the students $(n=101)$ had various problems, including spelling, vocabulary, grammar, punctuation, cohesive devices, coherence and organization. It was also reported that the most significant difficulty area was their ability to use cohesive devices. More recently, Tahvildar and Emamjomeh Zade (2013) studied undergraduate university students' $(n=106)$ ESL writing problems. The samples written by the students were analysed in reference to their ability to use (i) ideas (including details, development, and focus), (ii) organization (internal arrangement and relevance to the central idea), (iii) voice (including tone, style, purpose, and audience), (iv) word choice (specific language and phrasing), (v) sentence fluency (accuracy, rhythm, and tempo), and (vi) conventions (mechanical accuracy, spelling, grammar, paragraphing, and punctuation). The results indicated that the students experienced different levels of difficulty when dealing with writing tasks. They found it easiest to address the writing task the easiest while they found it the hardest to handle language use.

\section{Method}

The present cross-sectional study was carried out in order to examine a group of Iranian EFL learners' ability in writing argumentative essays. Quantitative method was followed to meet this objective.

\subsection{Written Samples}

The data were collected from 17 male (25.8\%) and 49 female (74.2\%) Iranian EFL students, learning English at private English institutes in Tehran. The average age of the subjects was 24 . They were from intermediate ( $\mathrm{n}=32$ ), upper-intermediate $(n=25)$ and Advanced $(n=9)$ proficiency levels. The learners' first language was Farsi and majority of them reported that they had been studying English over the past five years. In order to collect the data, the following argumentative topic was assigned to the learners.

Do you think it is easier to learn English in an English-speaking country than Iran? What are your reasons for your answer?

The students were asked to write an essay with approximately 250 words about the given topic in 45 minutes during their class time and subsequently they were requested to submit their essays to their teachers.

\subsection{Instrument}

The scale that was used for rating the samples was the Prototype Analytic Argumentative Writing Scale (PAAWS) (Nimehchisalem, 2010). It is a genre-specific analytic scale with seven subscales of (1) task fulfilment, (2) Content, (3) Organization, (4) vocabulary, (5) style, (6) grammar, and (7) mechanics. The scale was developed based on an integrated model informed by the Theory of Communicative Language Ability (Bachman, 1990), Taxonomy of Components of Language Competence (Bachman, 1990), Theory of Classical Rhetoric (Kinneavy, 1971), and Model of Argument (Toulmin, 2003). The model is called the Pyramid of Argumentation (Nimehchisalem, Chye, Singh, Siti Zaidah, Norouzi, \& Khalid, 2014). The scales was developed based on a survey (Nimehchisalem \& Mukundan, 2011), a focus group study (Nimehchisalem, Mukundan, \& Shameem, 2012), and a data-based analysis of a selected batch of samples (Nimehchisalem \& Mukundan, 2013). The subscales carry different weights with task fulfilment having the highest (17\%) and mechanics having the lowest (11\%) weights. A very high Cronbach's alpha coefficient (0.986) was obtained for the overall internal reliability of the average of the scores assigned by the two raters.

\subsection{Raters}

Two Iranian English language teachers holding master's degrees in English language teaching and having experience of 9 years of teaching English scored the samples individually. Pearson Product Moment analysis indicated high to very high inter-rater reliability coefficients for each of the subscales: task fulfilment $(r=0.84)$, Content $(r=0.86)$, Organization $(r=0.92)$, vocabulary $(r=0.95)$, Style $(r=0.92)$, grammar $(r=0.96)$, and mechanics $(\mathrm{r}=0.92)$.

\subsection{Data Analysis}

IBM SPSS (Version 21) was used for data analysis. Before analyzing the frequency and percentage of the data, the average of the scores assigned by the two raters was computed.

\section{Results}

This section presents the results of the study, following the order of the research questions. The first research question concerned the Iranian students' performance level regarding their task fulfilment skills. Based on the 
results illustrated in Table 1, the majority of students (39.4\%) demonstrated Competent followed by Modest (31.8\%), and Very Limited (21.2\%) performance levels.

Table 1. Task fulfillment results

\begin{tabular}{ccc}
\hline Level & Frequency & Percent \\
\hline Very limited & 14 & 21.2 \\
Basic & 1 & 1.5 \\
Modest & 21 & 31.8 \\
Competent & 26 & 39.4 \\
Excellent & 4 & 6.1 \\
Total & 66 & 100 \\
\hline
\end{tabular}

Table 2 shows the students' performance in reference to their ability to provide effective, mature and relevant content in their arguments. Based on these results, a considerable proportion of the students indicated an excellent level of performance regarding the content of their writing.

Table 2. Content results

\begin{tabular}{ccc}
\hline Level & Frequency & Percent \\
\hline Very limited & 9 & 13.6 \\
Basic & 0 & 0 \\
Modest & 3 & 4.5 \\
Competent & 11 & 16.5 \\
Excellent & 43 & 65.2 \\
Total & 66 & 100 \\
\hline
\end{tabular}

As the results of Table 2 show, most of the participants (about 65\%) presented 'Excellent' levels regarding the content of their argumentative samples. This suggests that majority of students who learn English in the selected language institutes are able to introduce a claim, maturely, provide relevant data to support their claim, back their warrants, and finally anticipate and account for rebuttals. There were a small minority (about $14 \%$ ) of participants who indicated 'Very Limited' levels; however, on average, the participants' samples were rated as competent or excellent in reference to their content.

The written samples were also scored in terms of their organization, which focuses on the learners' ability to develop well-organized introduction/narration/division, body, and conclusion, indicating cohesion and coherence. Table 3 presents the organization results.

Table 3. Organization results

\begin{tabular}{ccc}
\hline Level & Frequency & Percent \\
\hline Very limited & 9 & 13.6 \\
Basic & 2 & 3 \\
Modest & 2 & 3 \\
Competent & 24 & 36.4 \\
Excellent & 29 & 43.9 \\
Total & 66 & 100 \\
\hline
\end{tabular}

Based on the results, a large proportion of the participants indicated 'Excellent' (about 44\%) or 'Competent' (about 36\%) levels of organization ability. Very few students (about 14\%) achieved low scores in reference to the organization of their argumentative essays. On average, the participants indicated 'Competent' levels of organization skills.

Table 4 . Vocabulary results

\begin{tabular}{ccc}
\hline Level & Frequency & Percent \\
\hline Very limited & 9 & 13.6 \\
Basic & 4 & 6.1 \\
Modest & 11 & 16.7 \\
Competent & 31 & 47 \\
Excellent & 11 & 16.7 \\
Total & 66 & 100 \\
\hline
\end{tabular}


With regard to the vocabulary results of the argumentative samples (Table 4), most of the participants (about 47\%) presented 'Competent' levels. It suggests that students who learn English in the selected language institutes are able to deal with occasional incorrect word forms, phrases, or collocations; mostly using simple words as well as use of synonyms/antonyms to avoid repetition. Furthermore, about $16.7 \%$ participants revealed equal 'Modest' and 'Excellent' levels. It suggests that students who learn English in the selected language institutes are able to use appropriate simple-complex/technical words, phrases, collocations, idioms, or figures of speech. Moreover, they are able to deal with skilful use of synonyms/antonyms to avoid repetition. On the other hand, they could deal with incorrect word forms, phrases, or collocations in almost every other sentence. There was a small minority (about $6.1 \%$ ) of participants who indicated 'Basic' levels.

Table 5. Style results

\begin{tabular}{ccc}
\hline Level & Frequency & Percent \\
\hline Very limited & 10 & 15.2 \\
Basic & 8 & 12.1 \\
Modest & 14 & 21.2 \\
Competent & 26 & 39.4 \\
Excellent & 8 & 12.1 \\
Total & 66 & 100 \\
\hline
\end{tabular}

About half the participants displayed 'Competent' (39.4\%) and 'Excellent' (12.1\%) levels of performance regarding their style (Table 5). This means that majority of the participants could effectively present and justify arguments through a style which was reasonably engaging, correct, clear and appropriate. The remaining half of the samples written by the participants obtained 'Modest' (21.2\%), 'Basic' (12.1\%), and 'Very limited' (15.2\%) grades.

Table 6. Grammar results

\begin{tabular}{ccc}
\hline Level & Frequency & Percent \\
\hline Very limited & 13 & 19.7 \\
Basic & 16 & 24.2 \\
Modest & 18 & 27.3 \\
Competent & 11 & 16.7 \\
Excellent & 8 & 12.1 \\
Total & 66 & 100 \\
\hline
\end{tabular}

As the results revealed, the majority of participants had 'Modest' (27.3\%), 'Basic' (24.2\%), or 'Very limited' (19.7\%) levels regarding their ability to produce grammatical structures (Table 6). That is to say, they made frequent errors that sometimes blurred the meaning. Only a small minority $(12.1 \%$ and $16.7 \%)$ of the participants achieved 'Excellent' and 'Competent' grades in their argumentative essays.

Table 7. Mechanics results

\begin{tabular}{ccc}
\hline Level & Frequency & Percent \\
\hline Very limited & 28 & 42.4 \\
Basic & 18 & 27.3 \\
Modest & 8 & 12.1 \\
Competent & 7 & 10.6 \\
Excellent & 5 & 7.6 \\
Total & 66 & 100 \\
\hline
\end{tabular}

The participants received the lowest scores for mechanics. Almost half (42.4\%) the participants received 'Very limited' grades while about one-third $(27.3 \%)$ were graded 'Basic' (Table 7$)$. The results demonstrate the participants' failure to recognize the importance of spelling, capitalization and punctuation or their lack of control over these skills.

Overall, majority of the participants indicated equally Basic (28.8\%) or Modest (28.8\%) levels of writing performance, as shown in Table 8:

About 1 in 4 participants (25.8\%) had very limited writing performance levels. Only a small minority of the participants demonstrated Competent (10.6\%) or Excellent (6.1\%) levels. 
Table 8. Overall results

\begin{tabular}{ccc}
\hline Level & Frequency & Percent \\
\hline Very limited & 17 & 25.8 \\
Basic & 19 & 28.8 \\
Modest & 19 & 28.8 \\
Competent & 7 & 10.6 \\
Excellent & 4 & 6.1 \\
\hline
\end{tabular}

\section{Discussion}

Based on the results of this study, the most problematic areas were grammar and mechanics. The results are almost similar to those of Tahvildar and Emamjomeh Zade (2013) who reported that the most problematic area for their participants was language use despite the differences between the samples in the two studies. These results may be attributable to the instructors' excessive emphasis on the content, implicit teaching of grammatical rules, and/or their failure in providing enough exposure or practice to enable their students to use grammatically well-structured texts. This may have resulted in the learners' failure to recognize the important role of proofreading their essays at the end of the writing process. Admittedly, another possible reason for the participants' relatively low grammar scores is that given more time, they may have been able to edit and improve the grammatical accuracy of their writings. The participants had only 45 minutes to generate ideas on the topic and write a 250 -word essay. The majority of participants, particularly those with low levels of proficiency could have found it very challenging to write well-organized and effective argumentative essays which were also grammatically accurate.

The objective of language Institutes in Iran is usually developing the communicative competence of their students. Most students who enroll in the institutes intend to prepare for international English proficiency tests like IELTS or TOEFL. Therefore, they need to develop their language skills to achieve acceptable scores on these tests. This is in contrast to what happens in English courses in Iranian schools. The school achievement tests and the university entrance exam almost exclusively focus on students' vocabulary, grammar and reading comprehension skills. The washback effect of these tests is that students, teachers and the learning-teaching materials focus on students' passive vocabulary knowledge, reading comprehension skills, and grammar skills, as shown by research on pre-university students and teachers' perceptions shows (Ghorbani, 2008). This has very strong pedagogical implications for the Ministry of Education. The results of this research clearly show that the syllabus and tests that English language institute students experience are relatively successful in developing their writing skills. Therefore, nation-wide projects should be planned at least to duplicate the same treatment and assessment procedures for teaching English at schools.

\section{Conclusion}

The current study was conducted to diagnose Iranian language institute EFL learners' specific areas of difficulty when writing argumentative essays. Writing in another language is a complex task which, at least as it is the case with lower proficiency level learners, they usually complete by thinking and writing in their L1 and then switching into their L2 (Kobayashi \& Rinnert, 1992). The picture becomes even more complicated as we consider other factors like the genre of the writing task, the linguistic and sociolinguistic relationship between the two languages involved, learners' proficiency levels, and their motivation to write in the language (Cohen \& Brooks-Carson, 2001). In order to make learners aware of such complexities and improve their writing performance more opportunities should be provided for them to practice writing. Unfortunately research findings show that students generally have insufficient practice in writing argumentative pieces (Applebee \& Langer, 2006). Therefore, the best way to improve Iranian EFL learners' argumentative writing skills is having them practice more.

As claimed by Nam (2006), writing an argumentative essay in English can be a difficult assignment for learners of English; thus, it is very important to provide them with instruction on the structure of English argumentative essays. Kaplan (1966) justified such difficulty, explaining that since logic and rhetorical structure are by no means a universal phenomenon but are culturally defined, a perfectly logical argument in one culture might be viewed as illogical in another. There are wide differences between Iranian students' L1 and L2 rhetorical structures which accentuate the need for carefully designed syllabi through which they learn the appropriate way to write effective argumentative pieces in English.

Generally, research shows that the majority of Iranian EFL students have high levels of writing anxiety which is attributable to "instructional practices, feedback received from writing instructors, and linguistic knowledge 
level" (Rezaei, Jafari, \& Younas, 2014, p. 1). Several researchers have recommended effective strategies to help learners develop their writing skills. For example, Khiabani and Pourghassemian (2009) showed how their students' quality of writing L2 essays increased when they learned to think in L2 and address native audience. Likewise, Shokrpour and Fallahzadeh (2007) found that in order to help students improve their writing performance the instructor should focus beyond surface language problems and on writing skills which enable learners to link their ideas together and generate coherence and cohesive texts.

The findings have implications for researchers in the area of Iranian EFL learners' writing skills. As it was discussed earlier, there are two distinct groups of EFL learners in Iran. Most of the available literature in this area fails to separate Iranian EFL learners who learned English at school from those who did so in language institutes. The results of this study showed that despite their weaknesses in grammar and mechanics, Iranian EFL learners who learn English in language institutes are generally able to develop argumentative content, organize ideas, and make appropriate word choices at a competent level. This finding is in contrast with that of Rezaei, et al. (2014), who declare, "most of Iranian EFL students have been found to have an inadequate competence in L2 writing" (p. 2) as well as the findings of several other researchers (Dastjerdi \& Samian, 2011; Jafari \& Ansari, 2012; Zaree \& Farvardin, 2009) cited by Rezaei et al. (2014). Further research is necessary on the comparison of the difficulties faced by the two groups of learners.

\section{References}

Applebee, A. N., \& Langer, J. A. (2006). The state of writing instruction in America's schools: What existing data tell us? Albany, NY: Center on English Learning and Achievement.

Azizifar et al. (2010). An analytical evaluation of Iranian high school ELT textbooks from 1970 to the present. Procedia Social and Behavioral Sciences 3, 36-44. http://dx.doi.org/10.1016/j.sbspro.2010.07.010

Bachman, L. F. (1990). Fundamental considerations in language testing. Oxford: Oxford University Press.

Birjandi, P., Alavi, S. M., \& Salmani-Nodoushan, M. A. (2004). Advanced writing. Tehran: Zabankadeh Publications.

Cohen, A. D., \& Brooks - Carson, A. (2001). Research on direct versus translated writing: Students' strategies and their results. The Modern Language Journal, 85(2), 169-188. http://dx.doi.org/10.1111/0026-7902. 00103

Cunningham, S., \& Moor, P. (2005). New Cutting Edge. New York: Longman.

Dastjerdi, V. H., \& Samian, H. S. (2011). Quality of Iranian EFL learners' argumentative essays: Cohesive devices in focus. Mediterranean Journal of Social Sciences, 2(2), 65-76. Retrieved from http://www.mcser.org/images/stories/2 journal/mjssmay2011/6.pdf

Ghorbani, M. R. (2008). The washback effect of the university entrance examination on Iranian English teachers' curricular planning and instruction. The Iranian EFL Journal, 2, 60-87.

Hemmati, F. (2001). Vocabulary problems in the EFL writing of Iranian students: Taxonomies and strategies (Doctoral dissertation, University of Essex).

Hinkel, E. (1999). Objectivity and credibility in L1 and L2 academic writing. In E Hinkel (Ed.), Culture in second language teaching and learning (pp. 90-108). Cambridge, UK: Cambridge University Press.

Jacobs, H., Zingraf, S., Wormuth, D., Hartfiel, V. F., \& Hughey, J. (1981). Testing ESL composition: A practical approach. MA: Newbury House Publishers.

Khiabani, N., \& Pourghassemi, H. (2009). Transfer of L1 organizational patterns in argumentative writing of Iranian EFL students: Implications for contrastive rhetoric. Iranian Journal of TEFLL, 1(4), 23-38. Retrieved from http://www.sid.ir/en/VEWSSID/J_pdf/1018220090402.pdf

Khodabandeh, F., Jafarigohar, M., Soleimani, H., \& Hemmati, F. (2014). Investigating Iranian EFL writing problems and examining back transfer. Asian EFL Journal 16(1), 227-270.

Kinneavy, J. A. (1971). A theory of discourse: The aims of discourse. Englewood Cliffs, NJ: Prentice Hall.

Lux, P. (1991). Discourse styles of Anglo and Latin American college student writers. Dissertation Abstracts International, 52(06A), 2128.

Nimehchisalem, V. (2010). Developing an analytic scale for argumentative writing of students in a Malaysian public university (Unpublished doctoral dissertation). Universiti Putra Malaysia, Serdang, Malaysia.

Nimehchisalem, V., \& Mukundan, J. (2011). Determining the evaluative criteria of an argumentative writing 
scale. English Language Teaching, 4(1), 58-69. http://dx.doi.org/10.5539/elt.v4n1p58

Nimehchisalem, V., \& Mukundan, J. (2013). Development of the content subscale of the Analytic Scale of Argumentative Writing (ASAW). Pertanika Journal of Social Sciences and Humanities (JSSH), 21(1), 85-104.

Nimehchisalem, V., Chye, D. Y. S., Singh, S. K. J., Siti Zaidah, Z., Norouzi, S., \& Khalid, S. (2014). A Self-assessment Checklist for Undergraduate Students' Argumentative Writing. Advances in Language and Literary Studies, 5(1), 65-80. http://dx.doi.org/10.7575/aiac.alls.v.5n.1p.65

Nimehchisalem, V., Mukundan, J., \& Shameem, R. G. (2012). Developing an argumentative writing scale. Pertanika Journal of Social Sciences and Humanities (JSSH), 20(S), 185-204.

Rezaei, M. M., Jafari, S. M., \& Younas, M. (2014). Iranian EFL Students' Writing Anxiety: Levels, Causes and Implications. English for Specific Purposes World, 15(42), 1-10. Retrieved from http://www.esp-world.info/Articles_42/Documents/Jafari.pdf

Richards, J. C. (2012). Interchange. Cambridge: Cambridge University Press.

Safarnavadeh, K., Aliasgari, M., Mosapour, N., \& Ananisarab, M. (2009). Evaluation of high school English language textbook based on the criteria derived from communicative approach to teaching. Journal of Curriculum Studies (J.C.S.), 5(17), 86 -114.

Shokrpour, N., \& Fallahzadeh, M. H. (2007). A survey of the students and interns' EFL writing problems in Shiraz University of Medical Sciences. The Asian EFL Journal Quarterly, 9(1), 147-163. Retrieved from http://www.asian-efl-journal.com/March_2007_EBook.pdf

Tahvildar, Z., \& Emamjomeh Zade, A. (2013). Evaluation of Writing Skills and the Levels of Difficulty. Journal of Academic and Applied Studies (Special Issue on Applied Sciences), 3(9), 53-63. Retrieved from http://academians.org/Media/Default/Articles/September2013/september2013-5.pdf

Toulmin, S. (1958). The uses of argument. Cambridge: Cambridge University Press.

Zhu, W. (2009). Performing argumentative writing in English: Difficulties, processes, and strategies. TESL Canada Journal, 19(1), 34-50. Retrieved from http://files.eric.ed.gov/fulltext/EJ659483.pdf

\section{Copyrights}

Copyright for this article is retained by the author(s), with first publication rights granted to the journal.

This is an open-access article distributed under the terms and conditions of the Creative Commons Attribution license (http://creativecommons.org/licenses/by/3.0/). 